\title{
The transition to a democratic Portuguese judicial system: (delaying) changes in the legal culture*
}

\author{
João Paulo Dias ${ }^{\dagger}$
}

\begin{abstract}
The Revolution of 25 April 1974 had a strong impact on justice in Portugal. Initially, it can be said that there was evidence of a process of democratisation involving the judicial structures, together with effective improvements to conditions allowing for independent and autonomous professional performance. However, in analysing the course of judicial reforms, it can be seen that changes took place more on a legislative level than in terms of the performance of the courts, proving that the evolution of the judicial system still demands a change of the legal culture. Therefore, the objective of this paper is to reflect on the evolution of the legal architecture in Portugal, seeking to determine whether the transition to a democratic judicial system is complete or whether, on the contrary, we are still faced with the process of justice in transition, delaying any changes in the current legal culture.
\end{abstract}

\section{Justice(s), democratisation, protagonists and social change: forty years after the Revolution}

The analysis of democratisation processes in various countries that have experienced dictatorships, such as Spain, Greece, Portugal or, more recently, Eastern and Central European countries, 'tends to present the construction of an independent judiciary either as an automatic consequence of the institutionalisation of democracy, or as one of the ceteris paribus conditions under which the behaviour of political actors unfolds' (Magalhães, I995, p. 5I). The courts and the judicial system as a whole are not, in general, a priority for the new political actors, who are more concerned with stabilising the political system, the functioning of public services and economic recovery (Przeworski, I99I; O’Donnel and Schmitter, 2013).

Transitional periods are always complex and difficult to analyse using a multidimensional approach, as the focus is often narrow and restricted to specific disciplines. It is essential to introduce a legal and political analysis within a historical context in order to observe trends, options, actors, attitudes and the performance of the judicial systems (Shapiro, I98I). Failure to consider any complex critical analysis of the evolution of the judicial system frequently leads to only partially drafted, limited reforms to improve the courts' ability to provide better justice for citizens (Hammergreen, 2007).

In Portugal, the process of democratisation after the Revolution of 25 April 1974 followed the same trend, with the major concerns of the new political actors focusing on completing the transition without provoking potential political conflicts between the different emerging parties.

* This paper was written within the framework of a broader research project entitled 'Who are our magistrates? A professional characterisation of judges and public prosecutors in Portugal', supported by the Portuguese Foundation for Science and Technology (PTDC/CPJ-JUR/I00390/2008 I FCOMP-oI-OI24-FEDER-0092 IO). In terms of rights and duties, judges and public prosecutors are two separate but parallel judicial professions in Portugal. In addition to carrying out a survey of judges and public prosecutors, the project also analysed the evolution of judicial reforms in Portugal during the last forty years, aiming to understand the complex interactions between politics and justice. This is the focus of the present paper.

$\dagger$ Centre for Social Studies, University of Coimbra, Portugal. Email: jpdias@ces.uc.pt; 〈http://www.ces.uc.pt/ investigadores/cv/joao_paulo_dias.php> 
In this sense, it is generally agreed that the Revolution was a success, although it had consequences that remain visible to the present day (Santos, I990, I994; Pinto, 20I I; Raimundo and Pinto, 2014). Therefore, the judicial system only became a priority in order to ensure democratic rule, as reflected in the long-standing tendency to marginalise the necessary investments and reforms to the judicial system and its professionals (judges, public prosecutors and judicial clerks). Forty years after the Revolution, it is accepted that the democratisation of the judicial system and the necessary changes to legal cultures is still incomplete (Dias, 2004, 20I2).

The aim of this paper is therefore to reflect on the impact of the changes that have taken place in the legal architecture in Portugal, ascertaining how, after four decades of democracy, the tensions, perplexities, obstacles and expectations generated at different times have managed to lead, in 20I4, to a democratically stable judicial system. It may be summarised in the form of a question: With what degree of certainty can it be said that today, forty years after the Revolution, the transition to a democratic judicial system (or rule of law, as it is often called in international literature $)^{\mathrm{I}}$ has achieved a significant level of maturity, allowing for changes in the legal culture? ${ }^{2}$ The answer to this question is essential to any reflections on the level of judicial activism, in a broader sense, which the judicial system has brought to the overall democratic system.

As Juan Carlos Ochoa claims, 'the observance of the rule of law in a given country is determined by political and economic structures, cultural norms, institutions and laws' (2015, p. 78). Therefore, the significance of these reflections is based on the need for in-depth knowledge of the process of setting up a democratic and efficient judicial system in a country such as Portugal, which has experienced only forty years of democratisation. The definition and implementation of concrete judicial reforms must therefore be integrated into this longitudinal analysis. The inability to do this, as described below, leads to a high risk of failure, severely damaging citizens' rights to fair and efficient justice.

Although it focuses on the Portuguese situation, this socio-legal-historical approach may prove very useful in setting up a framework for judicial reform in other contexts, providing new tools for a more complex analysis. ${ }^{3}$

\section{The construction of a democratic judicial system: key moments}

The Constitution for the new democratic regime was only approved almost two years after the Revolution, on 2 April I976.4 After the publication of the 1976 Constitution, which enshrined the

I In the sense expressed by Guillermo O'Donnell when he states: 'The rule of law is among the essential pillars upon which any high-quality democracy rests.... What is needed, rather, is a truly democratic rule of law that ensures political rights, civil liberties, and mechanisms of accountability which in turn affirm the political equality of all citizens and constrain potential abuses of state power. Seen thus, the rule of law works intimately with other dimensions of the quality of democracy. Without a vigorous rule of law, defended by an independent judiciary, rights are not safe and the equality and dignity of all citizens are at risk" (2004, p. 32).

2 With regard to 'legal culture', I follow David Nelken's approach, quoting his definition: 'Legal culture, in its most general sense, is one of describing relatively stable patters of oriented social behaviour and attitudes. The identifying elements of legal culture range from facts about institutions such as the number and role of lawyers or the way judges are appointed and controlled, to various forms of behaviour such as litigation or prison rates, and, at the other extreme, more nebulous aspects of ideas, values, aspirations and mentalities. Like culture itself, legal culture is about who we are, not just what we do' (2004a, p. I). See also Nelken (2004b, 20I2).

3 A comparative review of similar studies concludes that the chosen approach is not commonly used. Reviews of socio-legal studies in Portugal and Denmark, for example, reveal a prevalence of studies on 'how law is practised, how legal institutions work and, as part of that, how the legal profession takes part in both legal change and transformations of state and society' (Hammerslev and Madsen, 20I4, p. 397). In the case of Portugal, see Guibentif (20I4). A broader political analysis for the purpose of understanding legal and judicial changes is not often applied in the evaluation of a particular context or case study.

4 The Portuguese Constitution approved in I976, online: <www.parlamento.pt/Parlamento/Documents/CRPI976. pdf 〉. The present Constitution, online: 〈www.parlamento.pt/RevisoesConstitucionais/Paginas/Revisao2005.aspx 〉. 
courts as sovereign bodies, their independence was stipulated as one of the basic principles of the Portuguese judicial system, and their competences were defined (Marques, Pedroso and Gomes, I999, p. 4I3). Following this, the main laws on the organisation of the judiciary were approved in the following two years, an indication of the time required to implement a new judicial 'architecture' with the minimum coherence and articulation. However, this did not mean a radical break with the structures and, principally, the legal cultures and judicial practices inherited from the Estado Novo dictatorship. As various studies have confirmed, passing new legislation is not sufficient to change the judicial culture of its actors, who are, at the end of the day, the key figures responsible for improving performance in the field of justice.

A retrospective analysis enables historical periods to be established in which coherent reform trends can be identified. Naturally, the following proposed division is open to individual interpretation. It does, however, enable the vast number of interventions in the field of justice to be organised into six periods in a coherent and structured manner. This scheme is an improved and updated version of the analysis produced in previous works (Dias, 2004, 201 2; Dias, Fernando and Lima, 2008), supplemented with updated content resulting from later studies and developments.

\subsection{4-1976: a post-Revolutionary justice - the social and historical context}

The Revolution marked a structural change in Portuguese society, the consequences of which are still being felt today in terms of what has been achieved and what has not lived up to initial expectations. However, in any context, it is almost unanimously agreed that the transition to democracy was successful. Nevertheless, there are certain areas in which social change, including changes that have taken place at state level, has proved more lasting and produced better results than others. Amongst the various structural policies collectively pursued by the state, justice has followed a tortuous and ambiguous path which today has made it the target of major criticisms concerning its bureaucracy, slowness and inefficiency. The weak response it has managed to provide for the explosion in the number of court cases and the guarantee it offers of effectively realising citizens' rights are cited as critical aspects of its performance and capacity (Gomes, 20I I; Dias, 20I3).

The revolutionary context (I974-976) was characterised by a wide range of difficulties which restricted the capacity to construct a modern and effective social state. Essentially these included: (i) political and governmental instability, involving a series of provisional governments and an inability to define and implement a medium-term strategy; (ii) a serious social and economic crisis (the result of the economic system in force during the Estado Novo dictatorship and the energies invested in the Colonial Wars), which made it impossible to create a welfare state that could combat high levels of poverty and social exclusion; (iii) the return of Portuguese citizens who had been living in the former colonies, and the consequent process of integrating more than half a million citizens; and (iv) the lack of senior professional staff who could fill key positions associated with regenerating the state and society. Given this context, the reform of justice was a low priority, particularly since the ordinary courts essentially ruled on low-status conflicts that had little social relevance and were not, at the time, subject to any great pressures in terms of case-loads.

After the Revolution, and the establishment of a democratic regime, a form of judicial organisation was introduced in which the potential for the political powers to interfere was considerably reduced (Magalhães, I995, I999). Successive reviews of the organic laws of the courts, the Public Prosecution Service and the Statutes of Judges abolished the powers of intervention and directives of the Ministry of Justice which still remained from the previous regime.

This climate of change in justice was first felt in the period immediately before 25 April 1974. Various controversies and events contributed towards a mood of discontent 'from the top down' which circulated within the judiciary, ranging from articles published in the newspapers by judges and lawyers, interventions organised by the Bar Association, and even studies and 
colloquiums held all over the country. These warning signs were increasingly symptomatic of a desire for change amongst legal and judicial actors (Miranda, I999; Rodrigues, I999a, I999b).

Nevertheless, the first changes only took place after 25 April. After the last prime minister of the dictatorship, Marcello Caetano, was deposed by the Movimento das Forças Armadas (MFA - Armed Forces Movement), justice policies were adopted which aimed to meet the democratic expectations of the population. The first measures adopted by the MFA heralded the smooth transition desired by the judicial actors. The first provisional governments, in which Salgado Zenha ${ }^{5}$ was the Minister for Justice, quickly sought to implement the necessary measures to remove the judiciary from the tutelage of the executive and legislative powers by, for example, altering the composition of the Judicial High Council and abolishing the plenary (political) courts. In this context, judicial trade union activity began to 'simmer', in particular in the Union of Public Prosecutors and the two organisations representing the judges (one association and one trade union, which had merged by the end of the I970s).

Under Salgado Zenha, a series of judicial reform committees were created which helped launch the debate on the future of the Portuguese judicial system, categorising the problems and proposing new paths. In an era of ideological 'ebullience', the debates rapidly deteriorated into solutions that were barely reasonable or minimally practical. Cunha Rodrigues considers illustrative in this respect, the question of the instruction judge in criminal cases, for which a model was adopted and maximised that was already in crisis in other systems' (Rodrigues, I999c, p. 7I). According to Pedro Coutinho Magalhães, the political discussions between the different parties exemplified two characteristics of the period.

'Firstly, the relative marginalisation of (or consensus on) the subject of judicial reform in the strategies of the political actors of the time, an impression that is reinforced if we observe the relative stability of the Ministry of Justice during the pre-constitutional period, both in terms of its office-holders and its policies. Secondly, it also shows how institutional choices regarding the organisation of the judiciary were presented and defined as the exclusive prerogative of the political parties who enjoyed democratic legitimacy in the Assembly.' (Magalhães, I995, p. 68)

Neither the new civil authorities nor the more radical military movements were particularly interested in greater independence and/or autonomy for the courts and their professionals. Nevertheless, this was inevitable, given the prevailing democratic winds which successfully saw off any attempts at control. Curiously enough, and despite an initial phase of 'purges' controlled by the Ministry of Justice, some of the 'new' leading judicial actors who were calling for an independent judicial system made the transition to democracy with a certain degree of stability, remaining in the posts they had occupied during the Estado Novo dictatorship (Magalhães, I995; Dias, 200I, 2004).

The judiciary was granted a significant level of independence, although the political actors, as Fernando Ruivo calls them, knew perfectly well how to 'make conservative use of independence' (Ruivo, I986, p. 369), thus preventing potential conflicts and authorising a 'non-aggression pact' of the kind that is common in periods of democratic transition and consolidation. What is mysterious is the fact that the political parties had, apparently, refrained from exerting any decisive influence over the judiciary and, more specifically, the bodies entrusted with the internal management of the judicial professions, which had a tradition of interfering with external judicial

5 Salgado Zenha was a lawyer and an opponent of the dictatorship, first as part of the Communist Party and later as a founding member of the Socialist Party in 1973 . He became a leading political actor in the transitional period after the Revolution, serving as minister of justice. 
independence in matters such as nominations, appointments, transfers, promotions and disciplinary action (Magalhães, I995; Dias and Almeida, 2010; Dias, 2012). The judiciary that emerged from this period, and is currently serving, incorporates principles that history has shown to be difficult to reconcile. On a par with its jurisdictional and functional independence in relation to other (executive and legislative) state powers, it includes office-holders of sovereign bodies within a dual organisation, namely judges and public prosecutors. The governance and disciplinary bodies comprise the High Council of the Public Prosecution, in the case of public prosecutors, and the High Council of Judges (in addition to another High Council for the Administrative and Tax Courts).

\subsection{6-1984: breaking with the past: towards effective judicial independence}

In the period immediately following the 1974 Revolution, many difficulties emerged in terms of consolidating a stable democratic regime. Government instability led to major indecision regarding how to advance with the process of democratising the country. As previously mentioned, and against the background of a social and economic crisis, it was decided to favour a peaceful transition of the judiciary to the new democratic regime, involving a clear policy of nonconfrontation with judges and public prosecutors. The main strategy was to approve new laws on the organisation of the judiciary and the statutes of the judges and Public Prosecution Service ${ }^{6}$ to help the professional judicial bodies adapt to the new democratic political context.

However, given the non-intervention in the renewal of the professional bodies, this was a crucial period involving the design and implementation of the future democratic legal architecture, which has been maintained, with certain adjustments of varying levels of importance, up to the present day. António Cluny (I992, p. I36) highlights four major changes that took place during this period which characterise the peaceful transition (and the political non-confrontation between state powers): (i) the autonomy of the judicial professions in relation to the political-governmental powers (removing restrictions on their independence and autonomy); (ii) the separation of careers, recognising the autonomy of the Public Prosecution Service in relation to judges and the government; (iii) the admission of women to the judicial professions, introduced soon after 25 April; and (iv) specialist training for the judicial professions, with the creation of a Centre for Judicial Studies (the two latter points are illustrative of adaptation to new democratic values). The incorporation of the Labour and Family and Juvenile Courts within the judicial system and the separate structure for the Administrative and Tax Courts represented another major change. As a result of these changes, citizens' access to justice became more democratic, although not necessarily easier.

However, some of these reforms were only possible following a review of the legislation on the organisation of the judiciary, essentially carried out by the first constitutional government between August 1976 and February 1978 under Almeida Santos, ${ }^{7}$ the (Socialist Party/PS) Minister for Justice at the time. Due to his efforts, and those of his assistants including the later General Prosecutor Cunha Rodrigues (I984-2000), ${ }^{8}$ the chapter on the courts was duly enshrined, as stipulated in the 1976 Constitution of the Republic, and the Law of the Courts

6 The Portuguese laws of the last forty years on the organisation of the judiciary (the courts), judges, public prosecutors and judicial training can be found in the Diário da República Eletrónico (the official parliamentary publication), online: 〈https://dre.pt/〉.

7 António de Almeida Santos became a member of the Socialist Party in I974 and played a major role in the democratic consolidation process after the Revolution, initially in the transitional governments, as minister for the decolonisation process, and later in the first two elected governments, as minister of justice.

8 José Cunha Rodrigues, a former judge and later general prosecutor (the head of the Public Prosecutors Office) for sixteen years (I984-2000), worked with Almeida Santos on the drafting of the new laws on the judicial architecture. He was a leading judicial actor with a significant political and judicial influence from the transitional period until 2000, when he left the Public Prosecution Service. 
Organisation, the Statutes of Judges and the Law of the Public Prosecution were approved.9 It should be noted that the LOMP was only approved, as a continuation of the work developed by Almeida Santos, when Santos Pais, who had been the Secretary of State for Justice, became Minister for Justice. The Law of the Centre for Judicial Studies had been approved in $1979,{ }^{\text {Io }}$ when Pedro de Sousa Macedo was serving as Minister for Justice. There were few changes in the early I980s up to I984, reflecting an intentional lull on the part of both political and judicial actors, and the need to establish a trial period for the reforms that had already been implemented, in addition to the serious economic and social crisis which claimed the attention of the successive governments (Santos, I990).

This series of laws demonstrates that even in a situation in which governments did not last longsometimes only a few months - it is possible to approve a relatively coherent sequence of cohesive reforms. The fact that the governments did not last very long prevented other important reforms to the judicial system from taking place sequentially, as was the case with procedural law in several legal areas. The reforms may not have been as far-reaching as desired, but still represented one of the most significant breakthroughs of the post-25 April period.

However, the difference between the spirit of the law and the everyday practices of the judicial 'machinery' (legal culture) and its professionals remained significant ,and is still evident today, clearly translating into a distinction between law in books/law in action. In the words of Boaventura de Sousa Santos, this situation reproduced something that was evident on a much wider scale in Portuguese society:

'At the level of its judicial-institutional matrix, the state reinforced itself and multiplied its means of action, enlarging the machinery and respective bureaucratic services and bureaucracies; it formalised and officialised vast areas of social life, covering them with a thick, heavy regulatory cloak. However, at the level of concrete and effective state practice, that is to say, the conjunction of state actions and omissions in routine social regulation, the official actions by the state seem to be waning and it appears to have lost the strength and motivation to mobilise the means formally available to it.' (Santos, I990, p. I35)

This observation is very important, bearing in mind the role played by law in social change, in the sense of the modernisation or evolution of traditional societies such as Portugal (Santos, I994, p. I43).

\subsection{5-1995: consolidation of the judicial system: increasing social pressures}

This third period of reform was driven mainly by a succession of (centre-right) Social Democratic Party (PSD) governments. Having been elected without a majority in I985, the fall of the government in 1987 following a no-confidence vote was subsequently transformed into an absolute majority in 1987, which was repeated in the I99I elections. The government could therefore proceed with reforms without the need for parliamentary negotiations. There were four governments during this period, but the only change made to the organisation of the judiciary before the PSD governed for ten years had been the change to the Statutes of Judges, approved as the central bloc government reached the end of its mandate (the PS and PSD governed as a coalition between June I983 and November 1985), which provided a glimpse of the approach to the forthcoming reforms to the legal architecture of the judicial system. In I985, the PSD Minister

9 Law of the Courts Organisation (Law no. 82/77 of 6 December - LOT)); Statutes of Judges (Law no. 85/77 of I3 December - EMJ); and Law of the Public Prosecution (Law no. 39/78 of 5 July - LOMP).

Io Law of the Centre for Judicial Studies (Decree-Law no. 374-A/79 of ro September - CEJ). 
was Mário Raposo, ${ }^{\text {II }}$ who, during the time in which he held office in the minority government, managed to get the reforms to the laws on the organisation of the judiciary passed (affecting the courts and the Statutes of Judges and the Public Prosecution Service).

The start of the new majority PSD government in I987 coincided with the swearing in of a new Minister for Justice, Fernando Nogueira. ${ }^{12}$ He remained in office until March 1990, when he was replaced during a government reshuffle by Laborinho Lúcio, ${ }^{\mathrm{I} 3}$ who had been the Secretary of State for the Administration of Justice. Fernando Nogueira's term of office was marked by the implementation of a long-awaited salary update, settling certain claims and calming the angry mood of the judicial professions at the time. Moreover, following the constitutional review of I989, approved during this period, the Public Prosecution as a whole began to be defined and conceived of as an organ of the judiciary (Cluny, I995). ${ }^{\mathrm{I}}$ These changes succeeded in reversing the increasingly undermined status of the courts and the judicial professions, which had made them a less attractive career option for jurists. It is sufficient to note that at the start of the I980s there were, on average, thirty to forty applications for more than roo places at the Centre for Judicial Studies (which provides training for judges and public prosecutors), whereas the situation today is completely the opposite (there are now more than I,000 applicants for forty to fifty positions).

The new PSD majority in I99I established Laborinho Lúcio as Minister for Justice. All the successive programmes emphasised, to a greater or lesser degree, the urgent need to renovate and expand judicial facilities and to increase human resources. A great deal was invested in this area, through the construction of new courts and the renovation of others, reflecting a policy of providing more resources and better means to respond to the increasing demand. Once the legal architecture had been established, it was time to provide the physical conditions and human resources for justice: the performance of justice would be a later concern.

One important change, since it involved modifications to the structure of the judiciary and professional competences, was introduced in 1987 with the simultaneous revision of the Code of Criminal Procedure and the Penal Code, leading to adjustments in all the services (in)directly affected by these changes. This reform granted greater powers to the Public Prosecution Service (in terms of criminal investigation), altering the existing model and seeking to respond to the increasing media focus on criminal justice (the first major trials) by making the Public Prosecution Service responsible for co-ordinating investigations (instead of the former Instruction Judge).

\subsection{6-2004: justice 'in crisis': legal reforms ahead of changes to legal cultures}

The period between I 996 and 2004 corresponded to the fourth period of reforms to the organisation of the judiciary. Governments wavered but the PS remained in power for six years, albeit without an absolute majority. After two years in government the PS stood down during its second term, leading to early elections and changes in the composition of the parties in the government. Two rather stormy years followed, with two absolute majority governments resulting from an alliance between the PSD and CDS/PP (right) which did not, however, serve their full terms due to the

I I Mário Raposo was a lawyer and politician. He was President of the Bar Association after the Revolution and minister of justice in three different governments, his longest term of office lasting from I 985 to I987. He was also the Ombudsman between I990 and I99I.

I2 Fernando Nogueira is a lawyer and former Social Democratic Party politician, who served in several governments between 1987 and 1995 .

I3 Álvaro Laborinho Lúcio was public prosecutor, director of the Centre for Judicial Studies and a retired judge of the High Court of Justice. He held several political positions associated with justice in the Social Democratic Party.

I4 Thus, in addition to independence itself, concepts such as autonomy and the power of initiative, in the words of António Cluny, finally became part of the characteristics of the Portuguese judiciary (Cluny, I997). 
resignation of Prime Minister Durão Barroso to take up office as President of the European Commission, and the dismissal of his successor, Santana Lopes, on the orders of the President of the Republic after a series of turbulent events. This period was characterised by the general notion of a 'crisis in justice' and the adoption of a reformist discourse, given the increasing inability of the courts to respond to the growing demand placed on them by citizens and companies to resolve their conflicts, and their failure to condemn powerful actors charged by the Public Prosecution Service in major corruption cases.

During this period the Minister for Justice for the PS government in its first term of office was Vera Jardim, ${ }^{15}$ assisted by the State Secretary to the Minister, Matos Fernandes, and the Secretary of State for Justice, Lopes da Mota. This combination aimed to establish a balance between the various legal professions: the minister was a lawyer and the secretaries of state were magistrates, one a judge and the other from the Public Prosecution Service (in line with the policy of consensus upheld by the prime minister of the time, António Guterres). However, the results did not prove very consensual, bearing in mind the reactions of the representatives of the legal professions as a whole, with the partial exception of the Public Prosecutors' Union. Nevertheless, it was during this period that the legislative changes relating to the organisation of the judiciary were implemented.

In its first term, the PS also approved new versions of the three laws on the courts, judges and Public Prosecution Service. It can therefore be observed that the need was felt every ten years to review the laws on the organisation of the judiciary without, in general, changing its initial structure. The following, for example, were maintained: the dual organisation of the judiciary, which is still the case today, comprising the judicial courts and the administrative courts; the two High Councils for judges - one for judges in the judicial courts and the other for those in the administrative courts (in addition to the High Council of Public Prosecutors).

With regard to the changes to the laws on the organisation of the judiciary, in addition to the fact that these did not follow the order scheduled for their enactment, an analysis of the statistical data shows that the objectives were far from achieved and appears to indicate that the problem of supply could not be solved merely by legislative changes to the courts and the statutes of the judicial professions. Instead, it required deeper reforms associated with the legal cultures and working methods used in the courts.

In this new period of legislative change, the first major piece of legislation to be approved was the Statutes of the Public Prosecution, followed by the Law of Courts Organisation. These changes culminated in the approval of the Statutes of Judges two months after the end of the Vera Jardim legislature. The main change introduced by these laws affected the Public Prosecution Service, altering its organisational structure by creating new investigation departments and improving the general career structure through the introduction of an obligation to appoint public prosecutors to certain specialist positions (also transposed to judges through the principle of parallelism).

In 2000, a new PS government, also without a majority, came to power, in which António Costa ${ }^{16}$ served as Minister for Justice. In the two years that lay ahead, new priorities were introduced, focusing on a clear bid for 'alternative' dispute-resolution mechanisms as part of the process of de-judicialising and de-legalising conflicts and greater investment in computerisation and the de-materialisation of procedures. The main objective was to combat the dizzying increase in the demand for courts, given that the available resources were expanding slowly. Despite all efforts, the statistical data showed a

I5 José Vera Jardim is a lawyer and a member of the Socialist Party who has held several political positions since I979, including minister of justice.

I6 António Costa is the leader of the Socialist Party in 2015 and a former lawyer. As a politician, he has served in several governments in various positions, mainly as minister. 
steady increase in pending cases in the courts, which neither extra human resources nor reforms (such as enforcement procedures) were able to reverse.

The two justice ministers who followed in the short-lived PSD-CDS/PP coalition pursued the previous policy with very slight changes. From the outset, the low status ascribed to them, together with their evident lack of resources and political relevance, prevented any structural reforms from being implemented or any improvements to the ability of the courts to respond to demand.

\subsection{5-2010: confrontation, reform and assessment: How to improve without resources?}

From the outset, the majority government led by the PS, considered here as defining the fifth period of reform, introduced a spirit of reform in various areas. In the field of justice, the new minister, Alberto Costa, ${ }^{17}$ sought to implement long- and medium-term measures through the reform of various codes, particularly in the area of criminal justice, principally by launching the reform of the organisation of the judiciary in three pilot areas (Santos and Gomes, 2006, 2010). However, the first measure taken, which proved highly controversial, was to cut judicial leave, in circumstances which were not clearly defined and gave rise to conflicting interpretations, in which it was viewed as the 'revenge' of the PS for the Casa Pia case, ${ }^{\mathrm{I} 8}$ for example, or as reducing the excessive privileges of magistrates in comparison to other office-holders in sovereign bodies and workers in general. Whatever the case may have been, this 'opening move' immediately set the tone for a climate of hostilities between the judicial professions and the political powers.

The objectives of the reforms were all, to a greater or lesser extent, publicly directed towards one main aim: improving the functioning of the judicial system, and, in doing so, guaranteeing more effective citizens' rights. The strategy was launched on two main fronts: changes to the model of the organisation of the judiciary, with implications for management practices, methods and support services (procedural dematerialisation, etc.), and continuing investment in new supplementary forms of applying/administering justice (such as de-legalisation, de-judicialisation and alternative or complementary dispute-resolution mechanisms).

A Pact on Justice ${ }^{19}$ was agreed between the PS and the PSD in order to advance certain judicial reforms, but was rapidly blunted after the new general prosecutor was chosen. Nevertheless, it still allowed for agreement on the reform of the organisation of the judiciary which, in part, pleased the judges (due to the way in which they would be 'in charge' of the new circumscriptions). During this phase, the political measures shifted from changing the legal architecture and increasing resources to withdrawing cases from the courts using new legal instruments. None of the changes involved introducing a new legal culture that would favour judicial activism.

The key aspects of this period included the need to rationalise the volume of work and manage human resources and working methods in the law courts, together with the need to ensure the

I7 Alberto Costa was an opponent of the dictatorship and a lawyer. As a member of the Socialist Party, he has served as minister of justice.

I8 Casa Pia is the name of a state-run children's home which was the subject of a paedophilia investigation involving many public figures, including political actors mainly associated with the PS. After many turbulent incidents, the evidence that emerged was very weak, proving once again that the judicial system has difficulties in dealing with important public actors. More recently, in November 20I4, the arrest of José Sócrates, the former prime minister from this period is, in some analyses, viewed as a continuation of these tensions between judicial and political actors, although the evidence of corruption amassed by the Public Prosecution Service appears to be substantial.

I9 The Pact on Justice, agreed in 2006 with the aim of reforming the judicial organisation, essentially dates back to the nineteenth century. The Pact came to an end due to political disagreements. The Pact is available online: 〈http://www.mj.gov.pt/sections/documentos-e-publicacoes/temas-de-justica/acordo-para-ajustica/downloadFile/attachedFile_fo/Acordo_Justica_Assinada_o8_09_2006.pdf?nocache=I I 57736I36.84 >. 
effective co-existence of a diversified formal justice system combined with informal solutions (Lúcio, 2002). These positions were expressed in the debates that took place, leading to a new set of reflections, even though the studies which substantiated the different options were not entirely satisfactory. The main exception to this was the process for the reform of the organisation of the judiciary, which was based on prior studies before it was formulated and implemented in the pilot districts (Santos and Gomes, 20I0).

The lack of financial means to implement certain reforms, including the full implementation of the reform of the judiciary by providing it with the necessary resources, has been one of the main factors involved in the evident failure of certain legislative changes introduced in recent decades. The most obvious case, which cuts across several governments and ministers for justice, is the reform of enforcement procedures, generally agreed to be one of the main factors impeding the efficient functioning of the judicial system. ${ }^{20}$ The lack of adequate investment has meant that the results obtained fall well below expectations, leading to new waste and new obstacles. During this period a new Law of the Courts Organisation (No. 52/2008 of 28 August) was approved, stipulating the measures required for the introduction of the reform of the organisation of the judiciary. The Statutes of the Judges and the Public Prosecution Service were altered to comply with the new law.

The new PS government, which came to power at the end of 2009 without an absolute majority, led to a change in the Ministry of Justice - now under Alberto Martins ${ }^{21}$ - with the clear aim of pacifying relations between the various judicial professions and the political powers, as well as managing the reforms that had already been launched and needed consolidating. It remedied various problems identified in legislation that had been passed earlier, as was the case with the Code of Criminal Procedure, correcting errors that were the result of hasty approval. However, at the beginning of 20II, in the context of the state debt crisis which led, for instance, to the closure of the new competition to admit judges and public prosecutors, significant tensions generated by cuts to salaries and other earnings could be observed. Simultaneously, there was an attempt to change the legal instruments in order to allow senior positions to be filled by appointment, particularly in the Public Prosecution Service. After a complex negotiation process involving the government and the general prosecutor, the changes were reduced to extending the retirement date and other minor amendments that enabled older professionals to remain in service for a few more years (important mainly in terms of senior positions). These changes also led to many judges and public prosecutors retiring before the new laws were approved, thus increasing the problem of the shortage of human resources, which would become more serious in the years that followed.

\subsection{1-2014: enforcing judicial reforms, cutting judicial resources}

20 I I was a landmark year in which the Memorandum of Understanding (MoU) ${ }^{22}$ was signed with the Troika (the European Union, the International Monetary Fund and the European Central Bank),

20 The Enforcement Law, included in civil litigation, is one of the main problems of the judicial system in Portugal. In 2002, the creation of a 'new' legal profession - executive agent - was approved, privatising the execution of debts decided by the courts. Although it aimed to remove a mass of litigation from the courts, the expected results were never achieved due to a lack of investment in other important related matters within the judicial system. For more information, see online: <http://solicitador.net/profissao/agente-deexecucao >.

2I Alberto Martins is a former leader of the student opposition to the dictatorship during the late I960s. He joined the Socialist Party after the 1974 Revolution and has held political office several times since, including as a minister in different governments.

22 The Memorandum was signed by the Socialist Party while it was still in power. The government fell immediately afterwards, and the Social Democratic Party won the elections and ruled during the implementation of this external financial programme, which ended in May 20I4. Nevertheless, the 
putting Portugal in the position of a 'bailed-out' state forced to undertake major reforms aimed mainly at reducing state expenditure in all areas. Within this sixth period, the judicial system was therefore forced to carry out reforms without any financial resources and to cut costs, reducing its capacity to respond to an unprecedented low level. The main target was now the efficient functioning of the courts in the area of enforcement, associated with economic and market needs. The European Union Justice Scoreboard clearly defines what is at stake when countries are going through an adjustment programme such as the one implemented in Portugal, stating that 'well-functioning justice systems are an important structural condition on which Member States base their sustainable growth and social stability policies. Whatever the model of the national justice system or the legal tradition in which it is anchored, quality, independence and efficiency are two of the essential parameters of an effective justice system.'23 The external process behind the reforms to the judicial system is proof of the increasing influence of the 'Europeanisation' politics forcing or influencing national decisionmaking powers (Bulmer and Radaelli, 2004; Sweet, 2002; Goetz and Hix, 200I).

In the past three years, the Portuguese judicial system has been trying to adapt to this harsh new context rather than actively search for new ways to improve its performance. The paths to be pursued are still not entirely clear, although the objectives appear to be to improve the functioning of the judicial system (including a new overall reform of the organisation of the judiciary), advancing rapidly, despite the scarcity of resources, in a process of consultation with the various legal actors that is more theoretical than actual. The options for the recent structural reform of the judiciary have therefore been very limited, due to the financial crisis which has severely restricted its implementation.

The government elected in June 20II (a centre-right and right coalition) was in charge of implementing the MoU in the area of justice, under the new minister of justice, Paula Teixeira da Cruz. ${ }^{24}$ In addition to reforming enforcement law in the area of debt collection, its main task was to set up the new judicial organisation which would reduce the number of courts and human resources (thus satisfying the Troika's demands to cut operating costs). After several proposals resulting from controversial internal studies (DGAJ, 20I2; MJ, 20I2), the ministry of justice approved a new Judicial Map (Law of Organisation of the Judicial System - Law 62/2013 of 26 August) that reduced the number of first instance courts from 3 I I to twenty-three main courts (composed of 218 Central Sections, plus 290 Local Sections replacing former courts) (DGAJ, 20I2; MJ, 20I2). Three main aims were pursued in the reform that was launched on I September 20I4: enlargement of the area covered by each main court, specialisation of legal areas and the introduction of a new model of court management.

This reform of the judiciary - which ignored all the previous pilot experiences and results, as well as objections from local and political representatives, the arguments of the legal profession and expert warnings - was planned and implemented in an unusually short period of time (two years). Given its complexity, and the steps required for its implementation (adapting buildings, computer networks, professional training, changes in legislation and software, amongst others), the political decision to implement this reorganisation in such a short time came as a complete

impacts and the need to proceed with the agreed reforms are still imposed by the MoU. Post-MoU monitoring continues under the Post-Programme Surveillance of Portugal, which can be consulted online: <http://ec. europa.eu/economy_finance/assistance_eu_ms/portugal/index_en.htm >.

23 This quote can be found on the European Union Justice Scoreboard website, which includes ample information on judicial reform processes in countries operating under an external adjustment programme due to the financial crisis. For more information, see online: <http://ec.europa.eu/justice/effective-justice/ scoreboard/index_en.htm>.

24 Paula Teixeira da Cruz is a lawyer and politician and has been a member of the Social Democratic Party since I995. 
surprise. The objective was clear: everything had to be done before the MoU expired, otherwise the financial support would be affected.

The public evaluation of two months of the new judicial organisation clearly revealed that the negative effects of this hasty reform would last for a couple of years. The media coverage showed a real judicial 'nightmare': the software crashed, bringing the courts to a complete standstill; the buildings were not prepared for the mass of cases and personnel; human resources were inadequately distributed, leaving many courts short-staffed; and the opening of several specialist courts and other judicial services in distant locations proved chaotic, due to the limited infrastructures of the main courts, and citizens and companies only received very limited information on the changes. Delays in legal procedures, trials and building work, together with the impossibility of filing cases due to the software crash, became headline news on a daily basis. The real legal impacts have not yet been estimated, nor have the financial costs been calculated. Moreover, the system has still not stabilised, in spite of several recent improvements (such as lengthy repairs to the software system to enable it to work properly).

These reforms proved that if the lessons of the past are not taken into consideration, then the same mistakes are repeated over and over again. The external pressure created by the MoU signed with the Troika forced the Portuguese government to make this structural change without a complete implementation plan and without preparing the necessary contingency measures. The past three years have therefore been defined by the reform of the judiciary, relegating other 'curative' legal changes introduced within the same external conditional context to matters of secondary importance. However, these measures have not focused on the 'preventive' side of the problem and were implemented without the resources needed to ensure success, thus completely contradicting the statement contained in the approved government programme of 20II: 'the reforms [of justice] to be developed and implemented can only be carried out with the involvement of the state bodies, the legal actors and their institutions and society as a whole' (PCM, 20II, p. 63).

\section{Forty years of democracy: transition, change and citizenship}

In the field of justice, certain general trends can be identified in the forty years of democracy summarised above which, in all aspects, question the success of the reformist drive witnessed in previous decades. Although influenced by a variety of contexts, this lengthy period of forty years ultimately only encompasses a short period of time in terms of historical analysis. Yet, given the importance of the structural moments that have been experienced, in particular the 1974 Revolution, together with what has been learned from transitional processes in many other countries, this makes the need for speedier but careful intervention imperative. In this sense, ensuring effective citizens' rights should be the main objective of justice.

The evolution of the judicial system has been governed by major trends which confirm that Portugal is still in a transitional phase, involving ongoing changes that remain more apparent than structural, in the name of citizens' rights or, in other words, the 'famous' justice in the name of the people. The six main trends of the last forty years may be reviewed as follows: 25

(I) minor changes to the judicial architecture which, in general, has maintained the structure it inherited from the Estado Novo dictatorship (including the professional bodies) - as previously stated. the organisation of the new judiciary only began in September 2014;

25 See, amongst others, several studies published over the years in Portugal, from which these key ideas on the evolution of justice in Portugal can be extracted: Pedroso, Trincão and Dias (2003), Dias (2004), Santos and Gomes (2006), Dias and Azevedo (2008), Dias and Almeida (2010), Dias (2012). In particular, see the numerous assessment reports produced by the Permanent Observatory on Portuguese Justice, online: 〈http://opj.ces.uc.pt/〉. 
(2) minimal changes to the legal architecture of the judicial governing bodies (despite a mass of legislation over the past fifteen years) to ensure the legal conditions for independent and autonomous justice, with no major breakthroughs that would essentially envisage making the courts more accessible to citizens;

(3) the discrepancy between the granting of substantial rights and benefits to the judicial professions (a policy of mutual aid between judges and public prosecutors - 'you push and I'll pull') and the duties and procedures for controlling and monitoring professional performance;

(4) reformist euphoria without diagnosis, planning, investment and assessment, creating continuous cycles of reforms which are the 'same old story';

(5) the preservation of a culture of scant dialogue and co-operative interaction between political and legal actors, as a result of real and artificial conflicts;

(6) the continuing excessive 'promiscuity' between justice and politics, involving the circulation of individuals (both magistrates and lawyers) within appointed posts that play a key role in the performance of the judicial system.

Despite this list, the evident increase in the courts' ability to respond to the huge rise in demand should be emphasised, or, in other words, their ability to deal with the litigation that has emerged as society has evolved, paralleling the situation in the majority of other so-called developed countries. As has been the case in Portugal in other areas of social intervention, such as health care or social security, it has been possible in just forty years to achieve a growth rate which, given that it started out from a very low position, places it almost on a level with the majority of other countries in the European Union.

The charts clearly show the evolution of case-loads in the lower judicial courts, ${ }^{26}$ as well as the human resources in the judicial system (judges, public prosecutors and judicial clerks). Figures I and 2 present the figures for cases in the judicial courts, demonstrating the rapid growth that has taken place since 1974. It is only possible to observe a positive performance, when the number of closed cases is higher than the number of new cases, over a short period of time.

The greatest increase in the number of pending cases in the judicial courts can be seen in the late I 990 and the beginning of the twenty-first century. I997 represents the milestone year when the number of pending cases surpassed the one million mark. The majority of cases handled by the judicial courts concern civil matters, totalling approximately 80 percent of the pending cases (the percentage is also similar for new and closed cases).

Figure 3 shows evidence of the impact of the financial crisis and the period following the Memorandum of Understanding signed with the Troika. The loss of more than I,500 judicial clerks put the performance of the courts at risk. A similar but less drastic trend can also be observed in the number of judges and public prosecutors. Only the legal measures that were approved to tackle the case-loads in courts have prevented a worse scenario from emerging, although some of these measures were controversial since they removed litigation from the courts by transforming it into administrative cases (allocated to the public administration rather than the courts).

However, various difficulties have remained, and their impact has contributed to the slow and inconsistent improvement in the performance of the judicial system in Portugal. A set of four

26 The following data only relates to the lower judicial courts, which constitute the majority in the overall judicial system, which also includes the Appeal Courts and the High Court of Justice. As in France, the Portuguese justice system also has a separate branch for Administrative and Tax Courts, although the caseloads and human resources are smaller. For more information on the organisation of the Portuguese judicial system, see Dias (2004, 2013) or the European E-justice Portal, online: <https://e-justice.europa.eu/ content_judicial_systems_in_member_states-I6-pt-en.do?member=I $>$. 


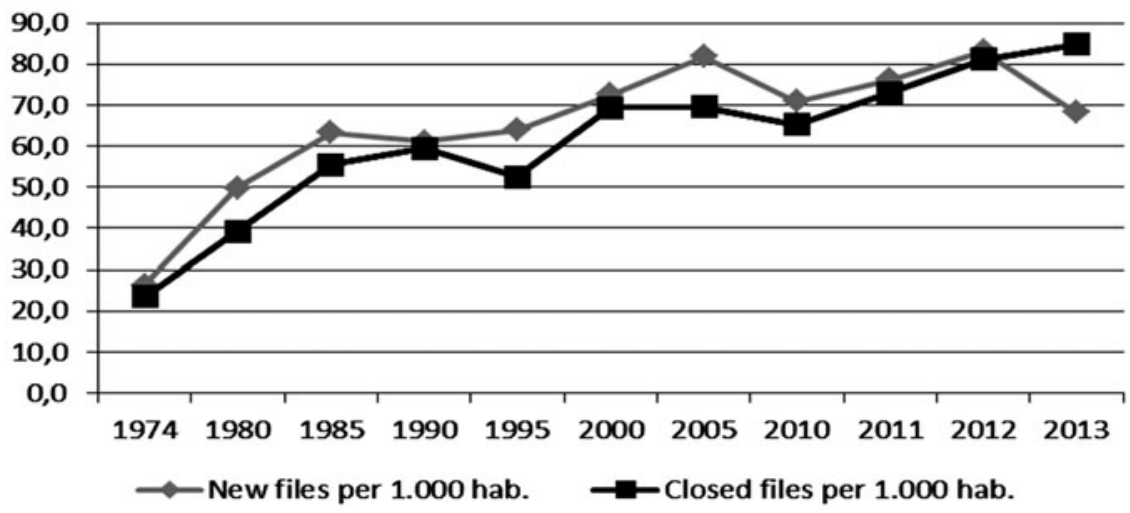

Figure $\mathbf{I}$

Lower Judicial Courts: new and closed cases per I,ooo inhabitants Source: PORDATA (www.pordata.pt), 2015.

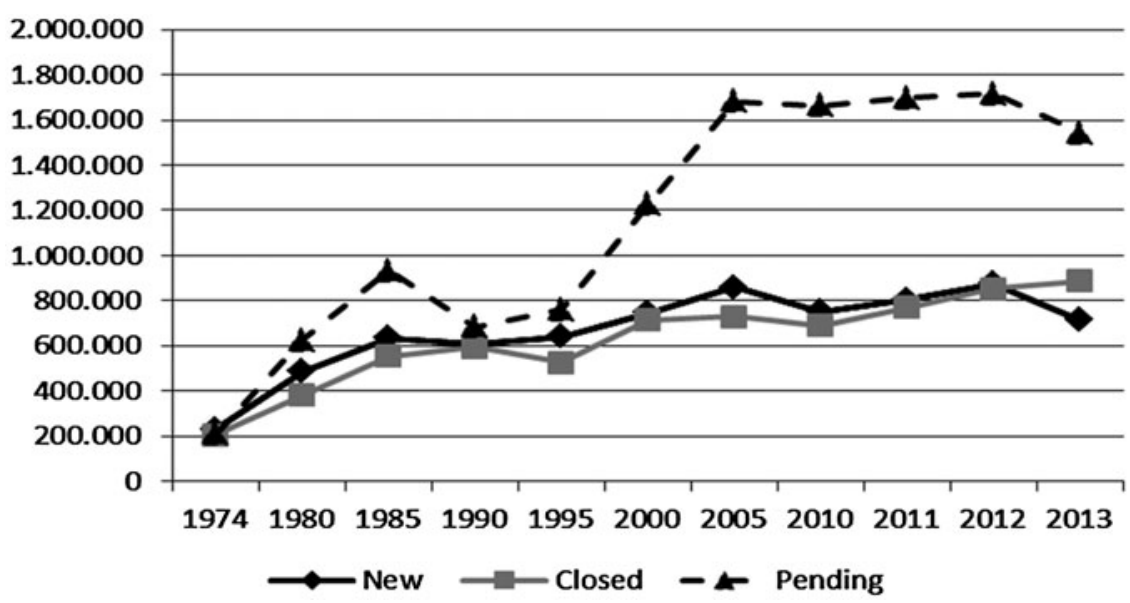

Figure 2

Lower Judicial Courts: new, closed and pending cases Source: PORDATA (www.pordata.pt), 2015.

particularly influential dimensions that have remained relatively stable may be cited in this respect, namely:

(I) the political dimension, associated with a lack of overall, scheduled planning and cuts to human, technical and financial resources (including those needed to implement the reforms that have been defined);

(2) the legal professions, associated with the scant (or excessive, in specific cases) involvement of legal professionals and other experts in providing support for analysing, defining and assessing reforms (including low investment in substantial ongoing training for the various judicial professions);

(3) the cognitive dimension, associated with the lack of information made available to the general public who, given the opaque functioning of the judicial system, remains largely uninformed; 


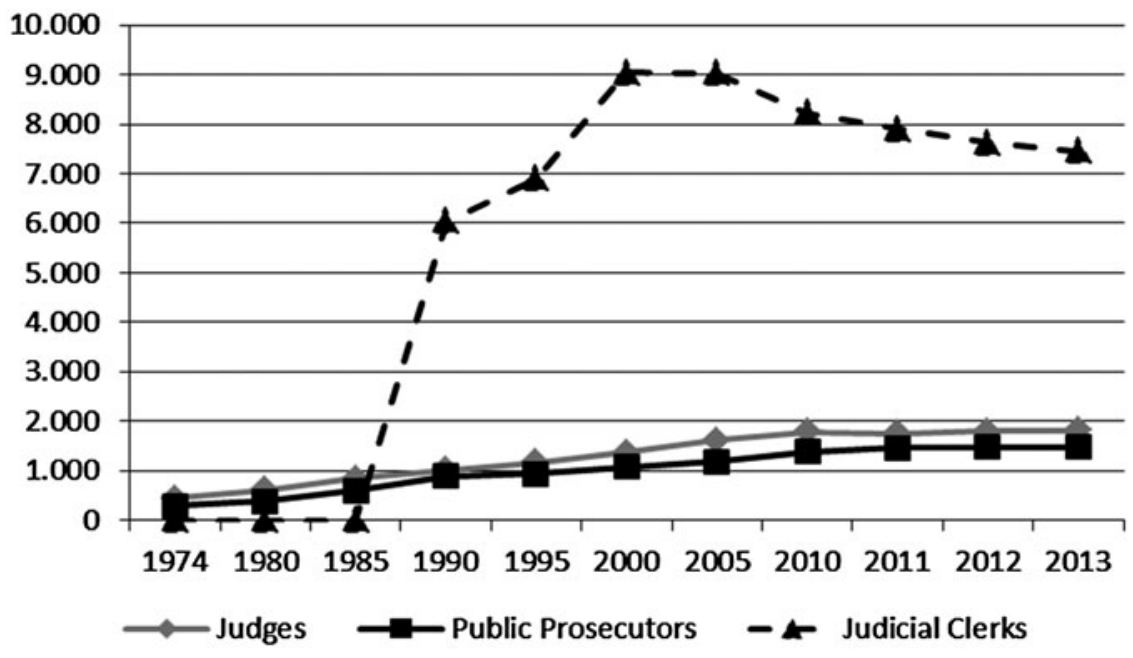

Figure 3

Judicial Courts: human resources

Source: PORDATA (www.pordata.pt), 2015.

(4) assessment, associated with a lack of studies and/or the scant use made of existing studies and the limited use of pilot studies to assess solutions before greater investments are made.

Within the context of the state debt crisis, recent years have shown that the Portuguese judicial system has not yet stabilised, and the danger of regression is real. It is not easy to anticipate whether a balanced judicial system will emerge from the current reforms, with an assured capacity to respond to the increasing demand and, fundamentally, the ability to guarantee citizens' rights in a swift and efficient way, providing real access to law and justice for all. The tension between 'judicial austerity' and judicial citizenship will remain the principal challenge for the judicial system in the near future, and will include both political and legal actors, and citizens.

\section{Final reflections}

Justice in Portugal is still involved in a process of consolidating the transition to democracy. Judicial systems are areas in which change takes place more slowly and with greater difficulty, not only because of the principles and modes of organisation that have been constructed over decades and centuries, but also because the professional bodies possess greater power and legitimacy, resisting any changes that might take place in their domain (Santos, I995). Whereas this resistance was for a long time seen as an obstacle to transparency and the democratisation of justice, nowadays the interpretations may be, and often are, very diverse: given the claim that as society is being eroded, the courts may be expected to serve as the last guarantors of effective citizens' rights, meaning that they have now to assume a strangely progressive stance.

An analysis of the evolution of the judiciary over the last four decades shows that the majority of interventions have been directed towards providing the judicial system with greater powers, within the principles of democratisation and independence. However, the problems of the judicial system are not limited to the legal or judicial architecture, but are largely dependent on the human, physical and financial resources at its disposal, and chiefly the empowerment and management of the professional bodies. 
Once the independence of the justice system was established, including powers of selfgovernance through the High Councils, the introduction of judicial reforms frequently faced opposition from the judicial professions (judges and public prosecutors). After a lengthy period dedicated to stabilising the operations of the judicial system and a focus on improving the performance of the courts in order to deal with increasing case-loads, new tensions have been observed in the past fifteen years as a result of the more accurate, or at least more damaging, activism on the part of the justice system directed towards political actors. The emergence of cases involving political actors has revealed a new period of confrontation, related to the maturity of the judicial system and an awareness of its power to confront the former whenever there is an attempt to reduce legal competencies or prerogatives.

Perfecting a democratic society implies, by necessity, a more democratic administration of justice, and it therefore does not suffice to reform procedural law or substantive law. The organisation of the judiciary has to be altered so that it can be democratised internally (Magalhães, I995; Santos I999a, I999b). Yet democratisation requires independence, responsibility and a legal culture of citizenship from the bodies responsible for managing the judicatures, which helps to create the changes in behaviour required to open up justice to citizens in a more transparent and less complex way.

In short, in an attempt to answer the question initially posed, it may be said that in terms of justice Portugal is still undergoing a process of transition and the consolidation of democratic values, combined with the pressures resulting from calls for reform reflecting the need for rapid, efficient and managerially perfect responses. Although this may be justified as being beneficial to citizens, the truth is that recent reforms of the judiciary have relegated the effective realisation of citizens' rights to a secondary issue and have not been able to resolve the difficult equation between citizens' rights and the efficiency of the justice system in any satisfactory and balanced way.

The importance of realising that the different trends associated with political options, judicial practices and legal culture somehow diverts attention away from fulfilling the 'purpose of justice' calls for a deeper acknowledgment of the need to incorporate the lessons of the recent past into plans for the future of justice through the implementation of judicial reforms. The novelty of these reflections lies in this argument, often neglected by the approaches of the social sciences and by political and judicial measures.

Forty years after the 1974 Revolution, it can be seen that much has been achieved within the Portuguese judicial system, through a process of transition and consolidation proceeding in slow but firm steps along the road towards the effective democratisation of its operations. Judicial activism, in this context, was always of secondary importance to the judicial professions and political actors, as the system was not yet ready to stand up for citizens' rights and challenge the powerful. Therefore, maturity will be achieved when justice functions in a way that manages to guarantee citizens' rights effectively, swiftly and without conceding to pressures to restrict the recent gains made by the Portuguese welfare state. In the face of the ongoing 'crisis in justice', as well as the recent (inter)national financial crisis, it is possible for judicial actors to emerge in support of the affirmation of equal justice for all.

\section{References}

BUlmer, Simon J. and Radaelli, Claudio M. (2004) The Europeanisation of National Policy?. No. poo42. Belfast: Queens University Belfast.

CLUNY, António (I992) 'Démocratie et rôle de l'associationisme judiciaire au Portugal' in Università degli Studi di Trieste and MEDEL (eds), La formation des magistrats en Europe et le rôle des syndicats et des associations professionnelles. Padova: CEDAM, I33-I4O. 
CLuny, António (1995) 'O Ministério Público o poder judicial', Cadernos da Revista do Ministério Público 6: $37-55$.

CLuny, António (I997) Pensar o Ministério Público hoje. Lisbon: Cosmos.

DGAJ (Direção-Geral da Administração da Justiça) (20I2) Ensaio para a reorganização da estrutura judiciária. Lisbon: Ministério da Justiça.

DIAS, João Paulo (200I) 'O "mundo" dos magistrados: a avaliação profissional e a disciplina', Revista Crítica de Ciências Sociais 60: 87-I20. Online: 〈http://www.ces.uc.pt/rccs/index.php?id= 755\&id_lingua $=\mathrm{I}>$.

DIAS, João Paulo (2004) O Mundo dos Magistrados: A evolução da organização e do auto-governo judiciário. Coimbra: Almedina.

DIAS, João Paulo (20I2) 'Estatutos das magistraturas e Conselhos Superiores: uma justiça em transição para a democracia no pós-revolução', in Fátima Moura Ferreira, Francisco Azevedo Mendes and José Viriato Capela (eds), Justiça na Res Publica (Sécs. XIX-XX). Braga: CITCEM, 220-255.

DIAS, João Paulo (2013) O Ministério Público no acesso ao direito e à justiça: 'porta de entrada' para a cidadania. Coimbra: Almedina.

DIAS, João Paulo and ALMEIDA, Jorge (2010) 'The External and Internal Conditions for the Independence of the Judiciary in Portugal', in Leny De Groot and Wannes Rombouts (eds), Separation of Powers in Theory and Practice: An International Perspective. Nijmegen: Wolf Legal Publishers, 225-252.

DIAS, João Paulo and Azevedo, Rodrigo (eds) (2008) O papel do Ministério Público no poder judicial: Estudo comparado dos países latino-americanos. Coimbra: Almedina.

DiAs, João Paulo, fernando, Paula, and Lima, Teresa Maneca (2008) 'O Ministério Público em Portugal' in João Paulo Dias and Rodrigo Azevedo (eds), O papel do Ministério Público no poder judicial: Estudo comparado dos países latino-americanos. Coimbra: Almedina, 28-70.

GoEtz, Klaus H. and hIX, Simon (eds) (200I) Europeanised Politics? European Integration and National Political Systems (West European Politics 23). London: Frank Cass.

GOMEs, Conceição (20II) Os atrasos da Justiça. Lisbon: Ensaios da Fundação Francisco Manuel dos Santos.

Guibentif, Pierre (2014) 'Law in the Semi-periphery: Revisiting an Ambitious Theory in the light of Recent Portuguese Socio-legal Research', International Journal of Law in Context IO(4): 538-558.

HAMmergreen, Linn (2007) Envisioning Reform: Conceptual and Practical Obstacles to Improving Judicial Performance in Latin America. Pennsylvania, PA: Penn State University Press.

hammerslev, Ole and madsen, Mikael Rask (2014) 'The Return of Sociology in Danish Socio-legal Studies: A Survey of Recent Trends', International Journal of Law in Context IO(3): 397-4I 5.

Lúcio, Álvaro Laborinho (2002) 'Justiça e Política - Um simples contributo', Revista do Ministério Público 90: 7-I6.

MAGALHÃEs, Pedro Coutinho (1995) 'Democratização e independência judicial em Portugal', Análise Social XXX(I 30): 5I-90.

MAGAlHães, Pedro Coutinho (I999) ‘Corporativismo, judicialização da política e a “crise da justiça” em Portugal', Revista do Ministério Público 79: I I-28.

MARQues, Maria Manuel Leitão, PEDroso, João and GOMEs, Conceição (I999) 'The Portuguese System of Civil Procedure', in A. A. S. Zuckerman (ed.), Civil Justice in Crisis: Comparative Perspectives of Civil Justice. Oxford: Oxford University Press, 4I3-44I.

MIRANDA, Jorge (I999) 'Le Conseil supérieur de la magistrature', in Thierry Renoux (ed.), Les conseils supérieurs de la magistrature en Europe. Paris: La Documentation Française, 257-270.

MJ (Ministério da Justiça) (20I2) Linhas estratégicas para a reforma da administração judiciária. Lisbon: Ministério da Justiça.

NeLKen, David (2004a) 'Using the Concept of Legal Culture', Australian Journal of Legal Philosophy 29: $\mathrm{I}-26$. 
nelken, David (2004b) ‘Comparing Legal Cultures', in Austin Sarat (ed.), The Blackwell Companion to Law and Society. Oxford: Blackwell Publishing, II 3 -I 27.

NELKEN, David (2012) ‘Using Legal Culture: Purposes and Problems’, in David Nelken (ed.), Using Legal

Culture. London: Wildy, Simmonds \& Hill Publishing, I-5 I.

осноA s., Juan Carlos (2015) 'Towards a Holistic Approach, in International Practice, to the Design and Implementation of Initiatives to Promote the Rule of Law at the National Level', International Journal of Law in Context I I(I): 78-9I.

o'Donnell, Guillermo (2004) 'Why the Rule of Law Matters', Journal of Democracy I5(4): 32-46.

o'donnell, Guillermo and schmitter, Philipe C. (2013) Transitions from Authoritarian Rule: Tentative

Conclusions about Uncertain Democracies. Baltimore, MD: John Hopkins University Press.

PCM (Presidência do Conselho de Ministros) (20II) Programa do XIX Governo Constitucional. Online:

〈http://www.portugal.gov.pt/media/I30538/programa_gc I9.pdf〉 (last accessed 5 September 2014). PEDROSO, João, TRINCÃo, Catarina and diAs, João Paulo (2003) Por caminhos da(s) reforma(s) da justiça.

Coimbra: Coimbra Editora.

PINTo, António Costa (ed.) (20I I) Contemporary Portugal: Politics, Society and Culture, 2nd edn. New York:

Columbia University Press.

PRZEWORSKI, Adam (I99I) Democracy and Market: Political and Economic Reforms in Eastern Europe and Latin America. Cambridge: Cambridge University Press.

raimundo, Filipa and PInto, António Costa (2014) 'From Ruptured Transition to Politics of Silence: The

Case of Portugal', In N. Wouters (ed.), Transitional Justice and Memory in Europe (I945-2013).

Cambridge: Intersentia, I73-I98.

RODRIGUES, Cunha (I999a) Lugares do direito. Coimbra: Coimbra Editora.

Rodrigues, Cunha (I999b) Comunicar e julgar. Coimbra: Minerva.

RODRIGUES, Cunha (I999) Em nome do povo. Coimbra: Coimbra Editora.

Ruivo, Fernando (I 986 ) 'A judicatura num período de crise do Estado', Revista Crítica de Ciências Sociais

I8/rg/20: 343-376. Online: 〈http://www.ces.uc.pt/rccs/index.php?id=253\&id_lingua $=\mathrm{I}\rangle$.

Santos, Boaventura de Sousa (I990) O Estado e a sociedade em Portugal (I974-I988). Porto:

Afrontamento.

SAntos, Boaventura de Sousa (I994) Pela mão de Alice - O social e o político na pós-modernidade. Porto:

Afrontamento.

santos, Boaventura de Sousa (1995) Toward a New Common Sense: Law, Science and Politics in the

Paradigmatic Transition. London: Routledge.

SANTos, Boaventura de Sousa (I999a) 'The GATT of Law and Democracy', Oñati Papers 7: 49-86.

SANTOS, Boaventura de Sousa (I999b) 'A crise (interna ou externa) dos tribunais', in Conselho

Económico e Social (eds), A justiça em Portugal. Lisboa: Conselho Económico e Social, I83-196.

santos, Boaventura de Sousa and gomes, Conceição (eds) (2006) A Geografia da Justiça: Para um novo

mapa judiciário. Coimbra: Centro de Estudos Sociais/Permanent Observatory on Portuguese

Justice. Online: 〈http://opj.ces.uc.pt/pdf/A_Geografia_da_Justica_Relatorio.pdf〉.

SANTOs, Boaventura de Sousa and Gomes, Conceição (eds) (2010) A Gestão nos Tribunais: Um olhar sobre a

experiência das comarcas piloto. Coimbra: Centro de Estudos Sociais/Permanent Observatory on

Portuguese Justice. Online: 〈http://opj.ces.uc.pt/pdf/RelatorioA_gestao_dos_tribunais_oI_04_20IO. pdf>.

SHAPIRo, Martin (198I) Courts - A Comparative and Political Analysis. Chicago: University of Chicago Press.

SWEET, Alec Stone (2002) Integration and the Europeanisation of the Law. No. poo24. Belfast: Queens

University Belfast. 